\title{
模型土質斜面の傾斜破壊実験と数値解

\author{
STATIC FAILURE TESTS BY INCLINATION ON MODEL SLOPES \\ OF SOILS AND NUMERICAL SIMULATION OF THEM
}

\author{
渡辺啓行*・五月女敦** \\ By Hiroyuki WATANABE and Atushi SAOTOME
}

\begin{abstract}
In the assesment of slope stability of soil structures against earthquakes, only conventional method such as so-called pseudo-static method is approved officially in aseismic design standard and seismic response analysis method is regarded as only supplemental method in Japan. In order to authorize seismic response analysis, it is necessary for the engineers to understand clearly the reciprocal relation between both methods. But the one concerning failure patterns set up by both methods remains unknown. In this paper, in order to clarify the mechanism resulting in each failure pattern, at first characteristics of failure supposed in conventional method will be discussed on the basis of experiments in which model slopes of sands are to be failured statically with the horizontal gravity force generated by inclination of them. Above test results will be simulated by FEM analysis combined with joint element method, then the patterns of statical failures of slopes will be clarified.
\end{abstract}

Keywords : slope stability, earthquake, pseudo-static, joint element

\section{1. 緒言}

日本における原子力発電所は, 立地条件からその敷地 面積が狭く，原子炉建屋が掘削残土から成る盛土斜面や 自然斜面に近接して配置される例が多い. したがって, このような斜面が地震時に崩壊しないことを確認するか 耐震対策を施しておかなければならない.

盛土や自然斜面の耐震性を評価する計算方法として, 日本では, 震度法によるすべり安定解析が公的に認めら れており, 動的解析は参考的に使われることが多い"1. しかしながら, 耐震設計に課せられる強い地震動に対し て設計震度をどのように設定するかなど不明瞭な部分が ある. そのため安全側として西日本にある T地点の例で は水平 0.36 , 鉛直 0.18 というピーク加速度に対応した 震度が設計震度に採用され, 過大な設計地震力を与える 結果となり，著しく不経済な安全対策を強いられた例が ある. 斜面やフィルダムあるいは土質地盤の地震応答解 析における動的解析法の妥当性は, 種々の観点からの検 討により確認されているが2) 5), 慣用法にかわるべきは ずの地震応答解析が公的に認められないことの一因は解

* 正会員 工博 埼玉大学助教授 工学部建設工学科 （テ338 浦和市下大久保 255）

** 正会員 工修 電源開発(株)建設部設計室
析結果から地震時すべり安定性を評価する手法が明瞭で なかったことにあると考えられる. しかし，土構造物に 対して, 累積ひずみ量あるいは地震後の沈下量を動的解 析と静的解析および材料試験から評価することによって 耐震設計を行う手法 ${ }^{61.7)}$ や，ロックフィルダムに対して, 潜在すべり土塊の逐次すべり変形量を動的解析から評価 することによって耐震設計を行う手法 ${ }^{81}{ }^{91}$ が， いくつか 提案されている. 土構造物等の耐震設計法を震度法から 動的解析法に移行するにあたっては, 両者の相互関係を 明らかにしておかねばならないであろう。解析的には部 分的に成功した例もあるが, 破壊パターンの相互関係は 未解明である.その解明にあたっては，おのおのの破壊 パターンを生ずる機構を分析しておく必要がある. 本論 文では, まず, 模型斜面の傾斜による静的破壊実験結果 に基づいて，その破壊特性を論じ，ついで，ジョイント 要素を導入した FEM 解析で実験をシミュレートする ことにより静的破壊パターンの分析を試みるものであ る.

\section{2. 模型材料の力学特性}

模型斜面に使用した材料は 2 種類の砂である. 1 つは, ある発電所地点において採取した洪積砂を自然乾燥した 後含水比を調整したもので, 日本統一土質分類法による 
粘土質砂 SC である. 他の 1 つは, 準標準砂といわれる 岐阜砂で, 統一分類法による SPu である. 後者は表層 すべりをみるために用いている．両材料の粒径加積曲線 を Fig. 1 に示す。洪積砂の物理特性は, 真比重：2.65, 液性限界： $25.1 \%$, 塑性限界： $18.9 \%$, 最適含水比： $16.2 \%$, 最大乾燥密度 $: 1.715\left(\mathrm{~g} / \mathrm{cm}^{3}\right)$ である. 岐阜 砂の物理特性は, 真比重 : 2.643 , 最大粒径 : $0.84(\mathrm{~mm})$, 均等係数 : 1.59 , 曲率係数 $: 1.25$, 最大間隙比 $: 1.126$, 最小間隙比：0.717 である.

\section{（1）洪樌砂の低拘束圧下の強さ定数}

洪積砂の模型は，全実験シリーズを通じて，平均間隙 比が約 1.1 , 平均含水比が約 $14 \%$ であったが, 強さ定 数に与える間隙比と含水比の影響をより正確に調べるた め, 間隙比を 1.1 に固定し，10，12，14，16（\%）の含 水比のおのおのについて拘束圧を $50 ， 100 ， 150 ， 200$ $\left(\mathrm{gf} / \mathrm{cm}^{2}, \times 98.0665 \mathrm{~Pa}\right)$ と変化させた 16 ケース, 含 水比を $14 \%$ と固定し，0.7，0.9，1.3の間隙比のおの おのについて拘束圧を上記 4 種に変化させた 12 ケース, さらに, 間隙比を 1.1 , 含水比を $14 \%$ に固定した条件

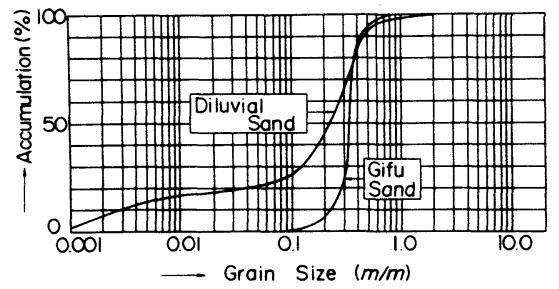

Fig. 1 Grain Size Accumulation Curves of Sands.
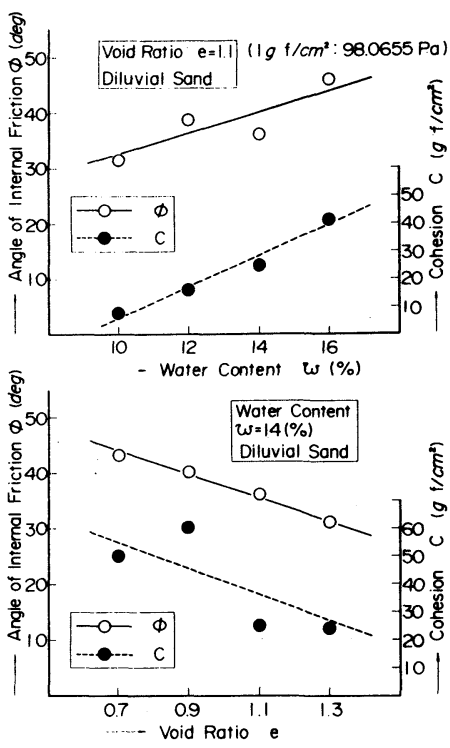

Fig. 2 Strength Constans-Void Ratio and Water Content Relationships of Diluvial Sand.
下で, 拘束圧を $10,20,40\left(\mathrm{gf} / \mathrm{cm}^{2}, \times 98.0665 \mathrm{~Pa}\right)$ と変化させた 3 ケースの合計 31 ケースについて, 直径 $75 \mathrm{~mm}$, 高さ $150 \mathrm{~mm}$ の円筒供試体 2 個ずつの三軸圧縮 試験を実施した。Fig.2は，これらの試験により測定さ れた強さ定数の含水比依存性と間隙比依存性を示したも のである.

上記結果において，拘束圧がきわめて小さいため，供 試体成形のためのゴムスリーブの拘束の影響が大きい. そこで, 洪積砂では, 含水による粘着力によって, ゴム スリーブがない場合でも供試体が自立する性質を利用し て，含水比を $14 \%$ に固定し，間隙比を $0.7 ， 0.9,1.1$, 1.3 と変化させた条件下でゴムスリーブを用いた場合と 用いない場合の一軸圧縮試験を行ってみた。各条件下で 2 供試体ずつの試験を行い，一軸圧縮強度 $q_{u}$ を求めた 結果を Fig. 3(a) に示す. 図より，ゴムスリーブのない 一軸圧縮強度は，ゴムスリーブのある場合より 16 33 \%小さくなっていることがわかる. ゴムスリーブの影 響は，粘着力に大きく現われると考えられるので，内部 摩擦角 $\phi$ は, ゴムスリーブの有無によって変化しない と仮定して，一軸圧縮強度よりゴムスリーブの存在に伴 う粘着力の見掛けの増加量 $\Delta c$ を次式により算定した.

$$
\Delta c=\frac{\Delta q_{u}}{2} \cdot \frac{1-\sin \phi}{\cos \phi}
$$

$\phi$ を Fig. 2 より求め, $\Delta q_{u}$ を Fig. 3(a) より求めて計算 した $\Delta c \sim e$ 関係を Fig. 3(b) に示す.

Fig. 2 上り, 含水比 $14 \%$, 間隙比 1.1 の洪積砂の強 さ定数は, $\phi=36^{\circ}, c=25.0\left(\mathrm{gf} / \mathrm{cm}^{2}, \times 98.0665 \mathrm{~Pa}\right)$ であったが，ゴムスリーブの影響を除いた後に $\phi=36^{\circ}$, $c=12.7\left(\mathrm{gf} / \mathrm{cm}^{2}, \times 98.0665 \mathrm{~Pa}\right)$ となった。

\section{（2）蚑阜砂の低拘束圧下の強さ定数}

岐阜砂の模型の気乾状態での間隙比は，0.76 0.81 である. 強さ定数に与える間隙比の影響を調べるため $0.79,0.87,0.95 ， 1.10$ の間隙比のおのおのについて 拘束圧を $50,100,150,200,300\left(\mathrm{gf} / \mathrm{cm}^{2}, \times 98.0665 \mathrm{~Pa}\right)$ と変化させた 20 ケースについて, 直径 $75 \mathrm{~mm}$, 高さ $150 \mathrm{~mm}$ の円筒供試体 2 個ずつの三軸圧縮試験を行っ た. 模型の平均的間隙比に対応した強さ定数は, $\phi=$ $27.5^{\circ}, c=10\left(\mathrm{gf} / \mathrm{cm}^{2}, \times 98.0665 \mathrm{~Pa}\right)$ となった. 強 さ定数に対するゴムスリーブの影響をみるため, Fig. 4 に示すように固定台上に厚さ $2 \mathrm{~cm}$, 直径 $20 \mathrm{~cm}$ の円形 に砂を敷き，裏面にサンドペーパーを貼付した直径 5 $\mathrm{cm}$, 厚さ $1 \mathrm{~cm}$ のアクリル板上の上載荷重を変化させて, 砂のせん断試験を行った．強さ定数は，Fig. 4 に示すよ うに, $\phi=25.5^{\circ}, c=0.664\left(\mathrm{gf} / \mathrm{cm}^{2}, \times 98.0665 \mathrm{~Pa}\right)$ となった. $\phi$ の変化は微少であるが, 粘着力は, 約 9.3 $\left(\mathrm{gf} / \mathrm{cm}^{2}\right)$ も減じている。この一面せん断試験と三軸圧 縮試験とは,せん断機構が必ずしも同じとは考えられず, 


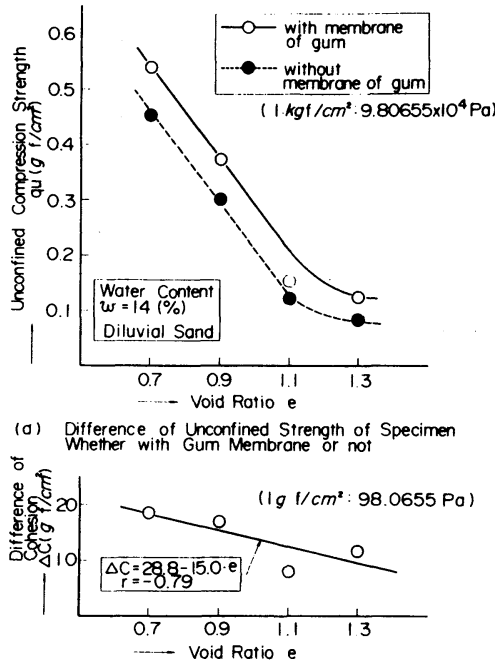

(b) Difference of Cohesion Coused of Gum Membrane

Fig. 3 Effect of Gum Membrane on Cohesion of Diluvial Sand.

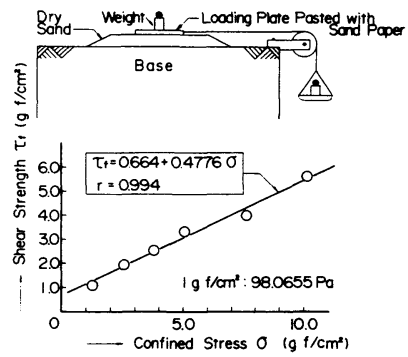

Fig. 4 Shear Strength-Confined Stress Relationships for Gifu Sand.

供試体の間隙比も 0.85 と三軸の場合よりやや大きいが, 見掛けの粘着力の低下量は洪積砂の場合と類似の値と なっている．そこでゴムスリーブの影響は洪積砂の結果 を妥当と考え，模型の破壊が一面せん断的表層すべりが 支配的と考えられるので，一面せん断試験結果を模型材 料の強度とみなす。

\section{（3）模型の強さ定数の代表値}

以上をまとめて, 斜面模型の平均的な間隙比と含水比 に対応した強さ定数の実験値とゴムスリーブの拘束を補 正して得た粘着力とを Table 1 に示す. 粘着力の補正値 の端数をまるめたものを模型実験の数値シミュレーショ ンに適用するものとして Table 1 に併せ示してある.

\section{3. 模型斜面の傾斜による静的破壊実験}

\section{（1）模型の種類と製作方法}

岐阜砂の模型は, Fig. 5 に示す Type 1 の基本形状で, 勾配を 3 種類に変化させた横断面を有する. 予備試験用 の 2 模型を含めた合計 5 模型を製作した。全模型とも，
Table 1 Strength Constants of Model Slopes Estimated from Laboratory Material Tests.

\begin{tabular}{|c|c|c|c|c|c|c|}
\hline Sorts of Sand & \multicolumn{2}{|c|}{ Conditions } & \multirow{2}{*}{\begin{tabular}{|c} 
Water \\
Content (\%)
\end{tabular}} & \multirow{2}{*}{$\begin{array}{l}\begin{array}{l}\text { Vold } \\
\text { Ratio }\end{array} \\
1.1\end{array}$} & \multirow{2}{*}{$\frac{\begin{array}{c}\phi \\
\text { (deg) }\end{array}}{36}$} & \multirow{2}{*}{$\frac{\left(\mathrm{gf} / \mathrm{cm}^{2}\right)}{25}$} \\
\hline \multirow[b]{3}{*}{ Diluvial Sand } & \multirow{2}{*}{$\begin{array}{l}\text { Experimental } \\
\text { Results }\end{array}$} & $\begin{array}{l}\text { With Effect } \\
\text { of Membrane }\end{array}$ & & & & \\
\hline & & $\begin{array}{l}\text { Wi thout Effect } \\
\text { of Membrane } \\
\end{array}$ & 14 & 1.1 & $36 *$ & 12.7 \\
\hline & $\begin{array}{l}\text { Values Applied } \\
\text { to Stability } \\
\text { Analysis }\end{array}$ & & - & - & 36 & 12.0 \\
\hline \multirow[b]{3}{*}{ Gifu Sand } & \multirow{2}{*}{$\begin{array}{l}\text { Experimental } \\
\text { Results }\end{array}$} & $\begin{array}{l}\text { Wi th Effect } \\
\text { of Membrane }\end{array}$ & 0 & 0.79 & 27.5 & 10.0 \\
\hline & & $\begin{array}{l}\text { Wi thout Effect } \\
\text { of Membrane } \\
\end{array}$ & 0 & 0.85 & 25.5 & 0.66 \\
\hline & $\begin{array}{l}\text { Values Applied } \\
\text { to Stability } \\
\text { Analysis }\end{array}$ & & - & - & 27.5 & 1.0 \\
\hline Remarks & \multicolumn{6}{|c|}{ * Assumption, $1 \mathrm{gf} / \mathrm{cm}^{2}: 98.0655 \mathrm{~Pa}$} \\
\hline
\end{tabular}

内法寸法が，幅 $0.65(\mathrm{~m})$, 長さ $2(\mathrm{~m})$, 深さ $0.5(\mathrm{~m})$ で側面にアクリル板の空を取り付けた鋼製試験槽内にお いて，斜面勾配の傾斜で鋼板を仮止めした内部に乾燥砂 を 5 層に分け，棒バイブレータで締め固める方法により 製作した。

洪積砂の模型は, Fig. 5 に示す Type 1 Type 3 の基 本形状で勾配を一定とした 3 種類，および Type 1 の基 本形状で勾配を別に 2 種類変化させた 5 種類の横断面を 設定し，各種類ごとに 2 模型とした合計 10 模型を製作 した. 全模型とも，内法寸法が，幅 $2(\mathrm{~m})$, 長さ $5(\mathrm{~m})$, 深さ $1.3(\mathrm{~m})$ で側面をアクリル板とした鋼製試験槽内 において，模型高さ $1(\mathrm{~m})$ を 8 層に分け，目標含水比 を $14 （ \%)$ とした湿潤砂を同一の人が足で踏み固める ことにより締め固め, 所定の高さに達した後斜面部を整 形することにより製作した．模型製作時に， 2 層分締め 固めるごとに数か所でサンプリングを行い，含水比と密
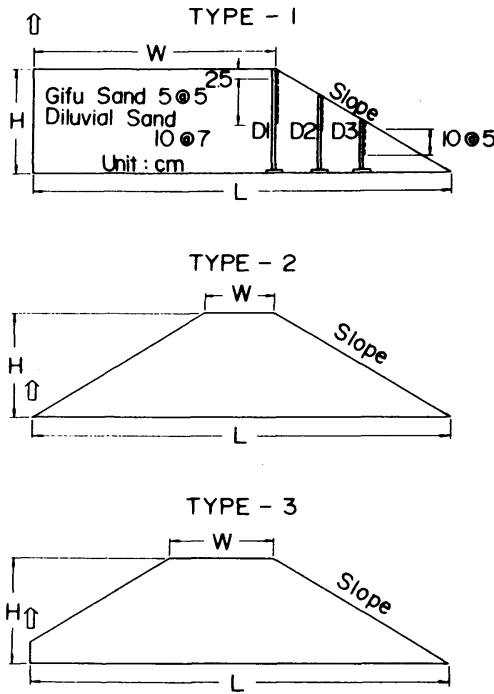

Fig. 5 Fundamental Forms of Model Cross Sections. 
度を測定した．全模型の寸法，形状，含水比，密度を Table 2 に示す． 各模型内には，すべり線の発生する時 期と位置を把握する目的で燐青銅板にひずみゲージを模 型寸法と位置によるすべり線深さに応じて岐阜砂模型で は $5 \mathrm{~cm}$ 間隔で 5 枚，洪積砂模型では $10 \mathrm{~cm}$ 間隔で最大 7 枚貼付けた変位計を埋設した．位置は，模型幅の中心 を通る鉛直面内で，岐阜砂模型では，Fig. 5 に示す D 1, 洪積砂模型では Fig. 5 に示す D 1 D 3 である．燐青銅 板の寸法は, 幅 $30(\mathrm{~mm})$, 厚さ $0.4(\mathrm{~mm})$, 長さ 500 $1000(\mathrm{~mm})$ である.

\section{(2) 実験方法}

模型斜面の破壊は，各試験槽底板の一端に取り付けた 回転軸受けまわりに，他端の砂箱上部をクレーンで吊り 上げることにより試験槽全体の回転を与え，模型を傾斜 させることにより発生させた。破壊傾斜角は予備試験に より見当をつけ,その近傍手前側の 4 10 度くらいから, 0.5 1 度刻みで傾斜角を漸増した。各傾斜角ごとにク ラック，すべり線発生状況を観測し記述した．破壊近傍 の傾斜角では， 5 分間静止して破壊発生がない場合に次 の段階の傾斜角を設定した。これは，洪積砂模型では， 破壊傾斜角に達してもただちに破壊せず，暫時静止状態 を保った後, 突然破壊する状況がしばしば認められたた めである.

傾斜角は, 試験槽側面に取り付けた下げ振りと分度器, ならびにあらかじめ傾斜角で較正したひずみゲージ型の 加速度計を底板に水平に取り付けたものとを用いて計測 した．変位計のひずみおよび加速度計による傾斜角はと もに動ひずみ計により電磁オッシログラフに同時記録し た.

\section{（3）実験 結 果}

岐阜砂模型の破壊状況の一例を Photo 1 に, 洪積砂模 型の破壊状況の一例をPhoto 2 に示し, 材料種別, 斜面 形状別の代表的すべり面形状を Fig. 6 に示す. また，す ベての模型の破壊を生じた傾斜角（破壊角）をTable 2

Table 2 Parameters and Angles of Inclination of Model Slopes.

\begin{tabular}{|c|c|c|c|c|c|c|c|c|c|c|c|c|}
\hline Model & Material & Type & slope & H (m) & $W(m)$ & L (m) & $\begin{array}{c}\text { Depth } \\
\text { (m) }\end{array}$ & $\begin{array}{l}\text { Water } \\
\text { content } \\
(₹)\end{array}$ & $\begin{array}{l}\text { Density } \\
\left(\mathrm{g} / \mathrm{cm}^{3}\right)\end{array}$ & $\begin{array}{l}\text { Angle of } \\
\text { Failure } \\
\theta \text { (deg) }\end{array}$ & $\begin{array}{l}\tan \theta \\
(\div k)\end{array}$ & $\begin{array}{l}G \sin \theta \\
\left(\mathrm{cm} / \mathrm{s}^{2}\right)\end{array}$ \\
\hline $\mathrm{Ml}$ & & 1 & $1: 2.0$ & 0.5 & 0.6 & 1.60 & 0.65 & 0 & 1.46 & 14.0 & 0.25 & 237 \\
\hline M2 & & 1 & $1: 2.0$ & 0.5 & 0.6 & 1.60 & 0.65 & 0 & 1.50 & 14.0 & 0.25 & 237 \\
\hline M3 & $\begin{array}{l}\text { Gifu } \\
\text { Sand }\end{array}$ & 1 & $1: 2.0$ & 0.5 & 0.6 & 1.60 & 0.65 & 0 & 1.49 & 14.0 & 0.25 & 237 \\
\hline M4 & & 1 & $1: 1.5$ & 0.5 & 0.5 & 1.60 & 0.65 & 0 & 1.48 & 4.0 & 0.07 & 68 \\
\hline M5 & & 1 & $1: 2.5$ & 0.5 & 0.5 & 1.60 & 0.65 & 0 & 1.50 & 19.0 & 0.34 & 319 \\
\hline M6 & & 2 & $1: 2.0$ & 1.0 & 0.7 & 4.70 & 2.00 & 13.2 & 1.39 & 38.0 & 0.78 & 603 \\
\hline M7 & & 2 & $1: 2.0$ & 1.0 & 0.7 & 4.70 & 2.00 & 13.6 & 1.39 & 39.0 & 0.81 & 617 \\
\hline M8 & & 3 & $1: 2.0$ & 1.0 & 1.4 & 5.00 & 2.00 & 14.0 & 1.40 & 37.5 & 0.77 & 597 \\
\hline M9 & & 3 & $1: 2.0$ & 1.0 & 1.4 & 5.00 & 2.00 & 13.5 & 1.38 & 38.0 & 0.78 & 603 \\
\hline M20 & Diluvial & 1 & $1: 2.0$ & 1.0 & 3.0 & 5.00 & 2.00 & 13.9 & 1.39 & 38.0 & 0.78 & 603 \\
\hline MII & Sand & 1 & $1: 2.0$ & 1.0 & 3.0 & 5.00 & 2.00 & 13.5 & 1.39 & 37.0 & 0.75 & 590 \\
\hline$M 12$ & & 1 & $1: 1.5$ & 1.0 & 3.5 & 5.00 & 2.00 & 13.9 & 1.38 & 33.0 & 0.65 & 534 \\
\hline $\mathrm{M} 33$ & & 1 & $1: 1.5$ & 1.0 & 3.5 & 5.00 & 2.00 & 13.7 & 1.36 & 34.0 & 0.67 & 548 \\
\hline$M 14$ & & 1 & $1: 2.5$ & 1.0 & 2.5 & 5.00 & 2.00 & 13.5 & 1.40 & 37.0 & 0.75 & 590 \\
\hline M15 & & 1 & $1: 2.5$ & 1.0 & 2.5 & 5.00 & 2.00 & 13.5 & 1.39 & 37.0 & 0.75 & 590 \\
\hline
\end{tabular}

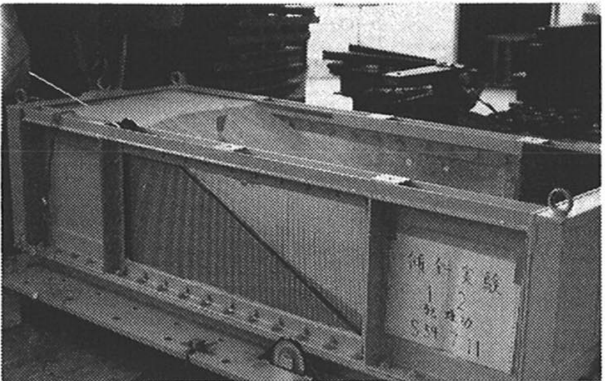

Photo1 Failure State of A Gifu Sand Model.

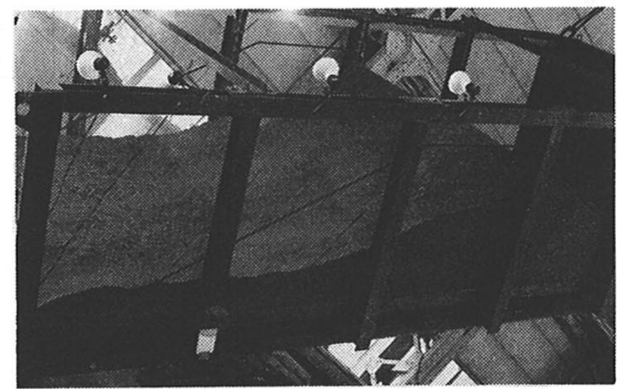

Photo2 Failure State of A Diluvial Sand Model.

に示す。

\section{4. 実験結果の考察}

\section{（1）岐阜砂模型の破壊特性}

岐阜砂模型は，乾燥砂より成るため，すべて表層すべ りであり，すべり層の厚さは高々数 $\mathrm{cm}$ 程度である.

Fig.6(a) に示すように，模型全幅にわたり，ほぼ平面

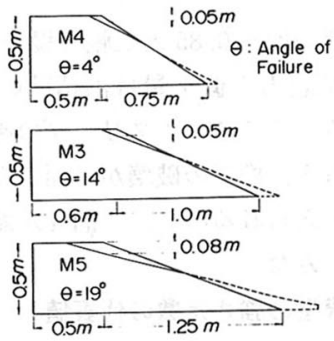

(a) Gifu Sand (Dry)

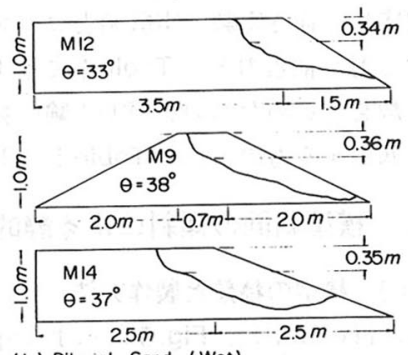

(b) Diluvial Sand (Wet)

Fig. 6 Typical Shapes of Sliding Surfaces of Models. 
状のすべり面がのり肩より発生する.すべり層の厚さは, 斜面勾配がゆるいほど，若干大きくなる傾向にある.

\section{（2）洪積砂模型の破壊特性}

洪積砂模型は湿潤砂を使ったため，粘着力がやや大き く,Fig.6(b) に示すように，深いすべりが発生してい る. クラック発生から崩壊に至る特徴を列記すると以下 のようになる.

a) Type 2 のように両側とも斜面をなす模型では, 傾斜角の増加に伴い，まず上方斜面に引張りクラックが 発生する. さらに傾斜角を増加していくと, クラックは, 徐々に成長しながらその先端からせん断クラックを発生 し，ついで内部にすべり線を断続的に発生しながら下方 斜面のり尻近くではらみ出し，表面に段差を生じる．最 後に断続的なすべり線が一本になって崩壊に至る. Type 1 のように斜面が片側のみにある模型では, 明確 なクラックや内部すべり面は, 後方盛土の変形が空隙に 追随するため現われない.

b）破壊すべり線は，いずれの Type も乾燥砂の場合 より深くほぼ円弧状をなす。しかし，すべり線上部は上 端から 30〜 $40 \mathrm{~cm}$ の深さまでは, 引張りクラックによ る剥離であって，ほぼ鉛直に近い段差を示している.

c）斜面全体の崩壊が, 破壊傾斜角に達した直後に発 生する場合は少なく, 数分経過後に発生するケースが多 い. 引張りクラック先端からすべり線や内部のすべり線 がクリープ状に成長して, ある限界長に達するか連続し た瞬間に崩壊を発生し，すべり線を境に上部土塊が一体 となってすべり落ちているといえそうである.

d）燐青銅板のひずみは，すべてのケースで全高の 2 分の 1 高さ斜面部に設置した変位計 D 3 (Fig. 5 参照) の最深部付近から発生し始め, 徐々に大きくなっていく. すなわち, 引張りクラック先端からのすべり線の成長と は別に, 斜面内部の比較的深い所でもすべり線が発生し ており，これが斜面下部のはらみ出しとなって現われて いると考えられる.すべり線の位置と全変位計の初期ひ ずみ発生位置とは,ほぼ一致する。

\section{（3）静的破壞に及ぼす斜面勾珚の影第}

模型を傾斜させて破壊する場合と水平震度 $k$, 鉛直震 度 $k_{v}$ を与えて破壊する場合とにおいて，すべり面勾配 を $\beta$, 傾斜角を $\theta$, 合震度が鉛直線となす角を $\alpha$ とする と, 重さ $W$ の土塊のスライス 1 片によりすべり面上に 発生するせん断力 $T$ と垂直力 $N$ とは, $T=W \sin (\theta+$ $\beta), N=W \cos (\theta+\beta)$ および $T=K \cdot W \cdot \sin (\alpha+\beta), N$ $=K \cdot W \cdot \cos (\alpha+\beta), K=\sqrt{k^{2}+\left(1-k_{v}\right)^{2}}$ となる. 両者 が等価であるためには $\sin \theta=\left(1-k_{v}\right) \tan \alpha=k, \cos$ $\theta=1-k_{v}$ でなければならない.ゆえに $k=\tan \theta$. $\sqrt{1-k^{2}} \fallingdotseq \tan \theta\left(1-0.5 k^{2}\right)$ となり, $0.5 k^{2} \ll 1$ 程度に $k$ が小さければ次式を得る. $k=\tan \theta$

Table 2 より $\theta$ は $33 \sim 39$ 度であるから $0.5 k^{2}=0.21$ 0.33 となり上記震度には $21 \sim 33 \%$ の誤差を伴う. 他方, $k^{4}=0.044 \sim 0.109$ 程度の誤差を許すなら $\tan ^{2} \theta=k^{2} /$ $\left(1-k^{2}\right) \fallingdotseq k^{2}\left(1+k^{2}\right)$ となり次式を得る.

$$
k=\sqrt{\frac{1}{2}\left\{-1+\sqrt{1+4 \tan ^{2} \theta}\right\}}
$$

式（3）で求めた $k$ を加速度単位で表わした $k \cdot G$ と 斜面勾配との関係を Fig. 7 に示す. Fig. 7 には電源開発 (株) (EPDC) が $\phi 10 \sim 60 \mathrm{~mm}$ の碟から成るロックフィ ルダム模型について行った振動破壊実験結果を重ねてプ ロットしてある．図より次のようにいえる.

a) 岐阜砂 (乾燥砂) 模型, 洪積砂 (湿潤砂) 模型之 も，静的破壊加速度は，斜面勾配がゆるやかになるにつ れて, それぞれ，ある上限值に漸近するように増大する. 湿潤砂模型では，上記変化が全体的に鈍い.

b）破壊加速度が斜面勾配に応じて変化する様相は, 振動破壊の場合と傾斜による静的破壊の場合とで類似し た傾向を示す.

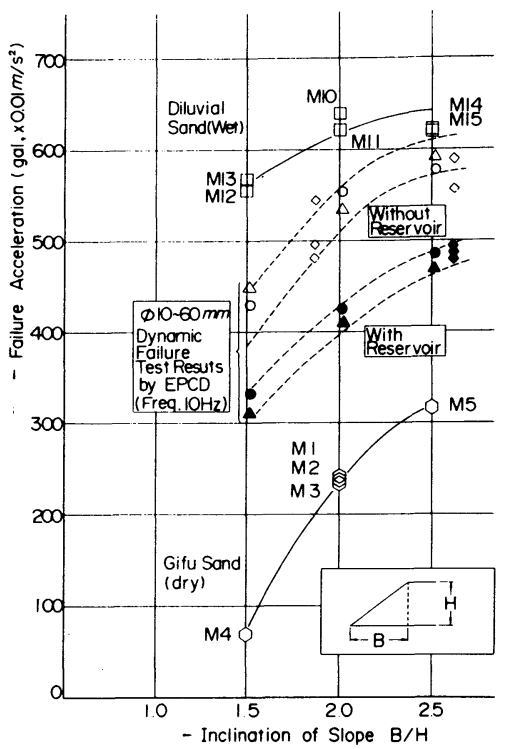

Fig. 7 Failure Acceleration-Inclination of Slope Relationships for Tested Models.

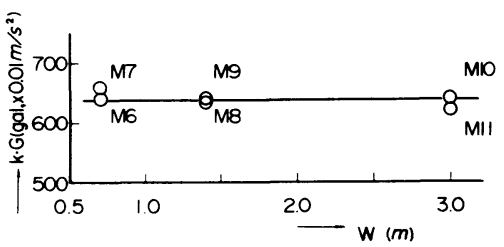

Fig. 8 Failure Acceleration-Top Width of Model Slope Relationship. 


\section{（4）静的破壊に及ほすす端幅の影響}

洪積砂模型のうち，斜面勾配一定で天端幅のみ変化さ せた場合の静的破壊加速度と天端幅 $W$ との関係を Fig. 8 に示す. Fig. 8 より，静的破壊加速度に及ぼす天 端幅の影響はほとんどないといえる。したがって, 静的 破壊加速度は主として斜面勾配に依存し，（2），a）で 述べたように, Type 1 の模型で可視的クラックの発展 が認められなくても, 内部的には Type 2 の模型で認め られたクラックの成長が生じているものと想像され, 破 壊過程は同一とみなせる.

\section{5. ジョイント要素を導入した FEM シミュ レーション}

岐阜砂模型では，Type 1 の形状を Fig. 9(a) に示す ように，洪積砂模型では，Type 2 の形状を Fig. 9(b) に示すように要素分割を行い，隣接要素間境界すべてに 導入したジョイント要素とによってモデル化した。

有限要素部分の物性に，岐阜砂模型においては三軸圧 縮試験結果の応力・ひずみ曲線の初期接線係数 $E=$ $12.5\left(\mathrm{kgf} / \mathrm{cm}^{2}, \times 9.80655 \times 10^{4} \mathrm{~Pa}\right)$, ポアソン比 $\nu=$ 0.25 , 密度 $\rho=1.46\left(\mathrm{~g} / \mathrm{cm}^{3}\right)$ を与え, 洪積砂模型にお いては同じく, $E=50.5\left(\mathrm{kgf} / \mathrm{cm}^{2}, \times 9.80655 \times 10^{4} \mathrm{~Pa}\right)$, $\nu=0.3, \rho=1.39\left(\mathrm{~g} / \mathrm{cm}^{3}\right)$ を与えた。

ジョイント要素の構成関係は，引張強度が不明である が $c$ が非常に小さいことを考えジョイント要素の垂直 方向の応力・ひずみ関係を Fig. 10(a) に示すように, 垂直応力が引張りを生ずるまではばね定数 $k_{n}$ をもつ線
形関係で与え，引張りとなるとき剥離状態としてジョイ ント内の全部材力をゼロになるようにしてあり，平行方 向の応力・ひずみ関係は，剥離していなければ，Fig. 10 （b）に示すように，せん断応力の絶対值が降伏応力 $\tau_{y}$ に至るまではばね定数 $k_{s}$ をもつ線形関係で与え， $\tau_{y} を$ 越えると滑動を生ずるようにしてある．垂直応力が引張 りから圧縮に変わる瞬間からは，残留ひずみを原点とす る Fig. 10 に示す処女状態にすべてが復するものとし， 剥離状態になく，せん断応力が降伏点を越えていた状態 からひずみの絶対值が減少し始めるときには, 残留ひず み位置から $k_{s}$ のばねに沿って応力の絶対値も減少する ようにしてある.せん断応力の降伏値には, モール・クー ロンの降伏条件を仮定して次式を与えた， $c$ と $\phi$ は先 に述べたように Table 1 に示す值を適用している.

$$
\tau_{y}=c+\sigma \tan \phi
$$

解析は, 実験と同じ状態を与えて荷重伝達法 ${ }^{11}$ の収束 計算を行った．すなわち，すべての要素に次式に示す震 度

$$
k_{M}=\sin \theta, \quad k_{v}=1-\cos \theta
$$

と重力加速度 $G$ に応じた物体力を与え, 傾斜角 $\theta$ を実 験で与えた順序で段階的に増加させていくものである.

ジョイント要素のばね定数は, 本論の解析の目的では 降伏または剥離を発生するまでは無限に用いことが理想 である．現実にはそれでは計算できないので適当な値を 仮定しなければならない，その目安は，弾性域の計算で 本来存在しないジョイントのばねによる変形が連続体要 素の変形に比較して十分小さくなることである.ジョイ

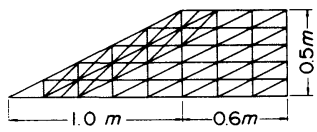

(a) Gifu Sand Model

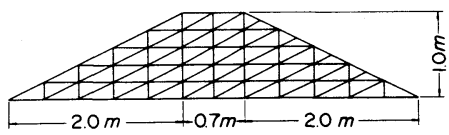

(b) Diluvial Sand Mode

Fig. 9 Finite Element Idealizations for Cross Sections of Simulated Models.

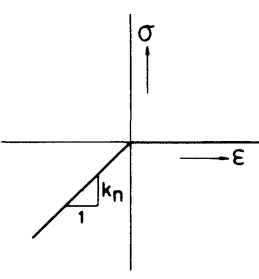

(a) Normal Direction

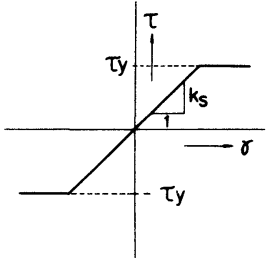

(b) Sheoring Direction
Fig. 10 Constitutive Relationships of Joint Element Properties.
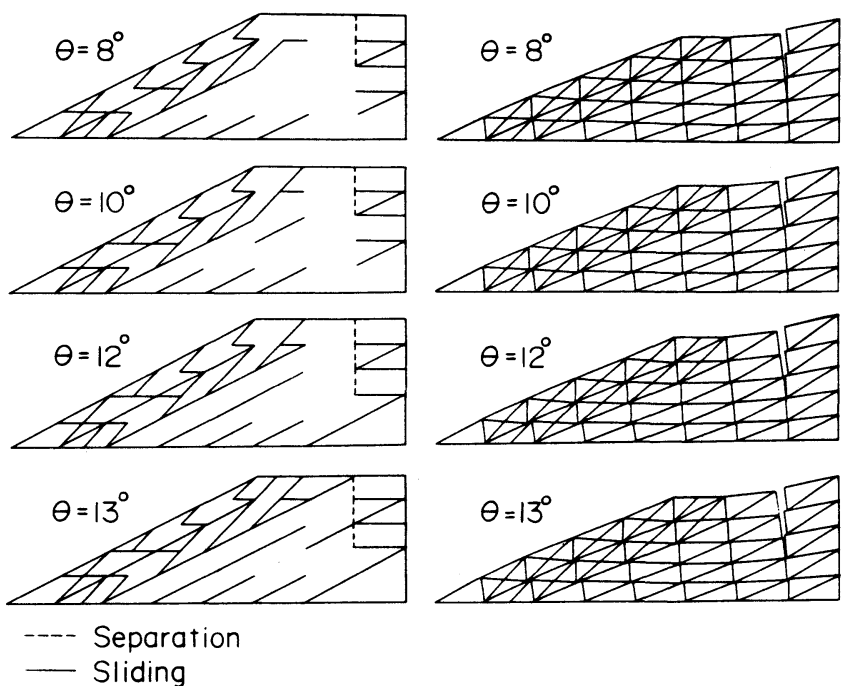

(a) Development of Discontinuous Elements

(b) Deformation

Fig. 11 Results of Numerical Simulation for Both Process and State of Statical Failure of A Model Slope of Gifu Sand. 

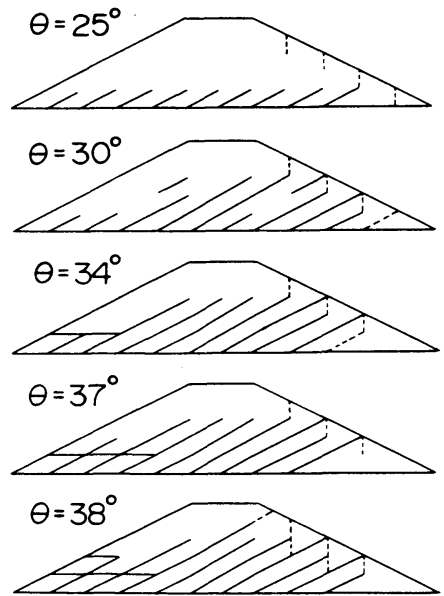

Separation

Sliding

(a) Development of

Discontinuos Elements

(b) Deformation

Fig. 12 Results of Numerical Simulation for Both Process and State of Statical Failure of A Model Slope of Diluvial Sand.

ントの応力・ひずみ関係の比例定数としての $k_{s}$ と $k_{n}$ との定義には，ひずみをジョイント要素の変位の次元で 表わす場合とジョイントの長さで除した無次元量で表わ す場合の 2 通りがある. 上述した目安として, 前者の定 義では, 矩形の連続体要素の高さ当たりの剛性率に対し て $k_{s}$, あるいは $k_{n}$ の値を，1 10 倍程度，実用的には 5〜6倍程度とれば工学的に十分な精度であることが経 験的に明らかにされている ${ }^{13)}$. 本論文では，この比率の 増大に伴う固有振動数の変動がほぼ完全に収束する值で ある $20 \sim 100$ にとり， $k_{s}$ と $k_{n}$ を上述後者の定義で与え て, 連続体の剛性率と同じ次元で表わし, $k_{s}=k_{n}=$ $1000\left(\mathrm{kgf} / \mathrm{cm}^{2}, \times 9.86055 \times 10^{4} \mathrm{~Pa}\right)$ とした.

各荷重段階での繰り返し計算の収束条件は, 全節点の 変位につき, 前回の変位に対する新しい変位の相対誤差 が $10^{-3}$ 以下となるように設定した.

以上のようにして計算した結果を，岐阜砂（乾燥砂） 模型について Fig. 11 に，洪積砂（湿潤砂）模型につい て Fig.12に示す.

\section{6. 数值シミュレーション結果の考察}

\section{（1）岐阜砂（乾燥砂）模型の数值解析による破塤特 性}

Fig.11 より次の特性が認められる.

a）傾斜角の小さい段階で，側方固定境界最近傍の上 端鉛直ジョイント要素に剥離を生じ，また，模型底では 斜面勾配に平行方向のジョイント要素のほぼすべてにす ベりを発生するが，実験では観察できない，模型の傾斜
角の増加につれて, これらすべり線群の うち, 斜面表面に近いものが上方に成長 していく，この成長は，表面近傍のすべ り線から深い位置のものへと伝播する. 荷重を増すと $\left(\theta=8^{\circ}\right)$ 内部に断続的な すべり線が多数発生すると同時に,のり 尻近傍の斜面表面から水平なすべり線が 発生して底部から上方に成長していた前 記すべり線と連結する．すべり線は天端 まで貫通していないので崩壊には至らな いが, 斜面表面のはらみ出し変形がかす かに認められる.さらに荷重を増すと $(\theta$ $\left.=10^{\circ} \sim 12^{\circ}\right)$ 斜面表面からの水平すべり 線が増し,はらみ出しも一層顥著となる. はらみ出しを生起している最表層のすべ り線より深い位置では天端から底部まで 貫通するすべり線が発生するが，底部で 寸断されるため崩壊には至らない，最終 荷重段階 $\left(\theta=13^{\circ}\right)$ では, はらみ出しを 生起している最表層のすべり線がのり肩 あるいは天端まで成長して, 天端からのり尻近くの斜面 表面まで貫通する不連続線を形成して崩壊する.

b）上記すべり線は，表面からの深さ $5 \mathrm{~cm}$ にある斜 面に平行な表層すべりといえる浅いものであり，実験結 果ときわめて類似している.

c）すべり破壊を生じた傾斜角は $13^{\circ}$ であり，実験結 果 (Table 2 参照) の $14^{\circ}$ と大変よく一致している.

\section{（2）洪䅡砂 (湿潤砂) 模型の数值解析による破壊特 性}

Fig. 12 より岐阜砂模型と違う次の特性か認められる.

a) 初期の荷重段階 $\left(\theta=25^{\circ}\right)$ で, 上方斜面上のいく つかの鉛直ジョイントが剥離を生じ，実験で観測された 引張りクラックと一致している．模型底で下方斜面に平 行方向のジョイント要素のほぼすべてにすべりを発生す るのは岐阜砂模型と同じである．これは，模型全重量に 対応する応力が底部に集中するので当然である．水平荷 重の増加につれて, これらすべり線群のうち, 模型最深 部のものが上方に成長していく．この成長は岐阜砂模型 と異なり深部から両側斜面近傍のものへと伝播する $(\theta$ $\left.=30^{\circ}\right)$. この成長するすべり線のうち，上方斜面下にあ るもの何本かは上方斜面の引張りクラックに連結する が,この不連続線は底部で寸断されるため崩壊には至ら ない.さらに荷重を増すと $\left(\theta=34^{\circ} \sim 37^{\circ}\right)$, 前記すべり 線の成長はさらに著しくなる.実験で観察されたものは, この状態と考えられる. また，下方斜面のり尻近くから 水平なすべり線が成長して，上述したすべり線の下方斜 面近傍のものから順次深いものに連結していき，はらみ 
出し変形を生ずる. 最終荷重段階 $\left(\theta=38^{\circ}\right)$ では, 上記 連結したすべり線のうち最深部にあるものがさらに上方 に成長して, 上方斜面のり肩近傍に引張りクラックを誘 発して，のり肩から下方斜面までを貫通する不連続線を 形成して崩壊する.

b）上記すべり線はのり肩からの深さ $60 \mathrm{~cm}$ にある 深いもので, 実駼結果と類似している. のり肩近傍の引 張りクラックは, 実験では鉛直に近く, 解析結果とやや 異なるが, 上端が引張りクラックである点は同じである.

c）すべり破壊を生じた傾斜角は $38^{\circ}$ であり，実験結 果と正確に一致している.

以上において, 要素分割の粗さにもかかわらず, 数値 シミュレーションは実験をよく表現しており，剝離やす ベり線発生・成長過程から斜面の静的破壊機構が明瞭に 理解されたといえる.

\section{7. 荷重伝達法における加速係数と収束性の吟} 味

非線形計算を荷重伝達法で行う際，ジョイント要素の ばね定数が連続体の剛性より大き過ぎると，繰り返し計 算の収束性が著しく悪くなる. 計算の加速法についてい くつかの提案がされているが(2)，本論文では，修正外力 に加速係数をかけることにより収束を早める方法を提案 し，そのようにした場合の収束性の吟味から加速係数と してとり得る値の範囲を設定しようとするものである.

考察を容易にするため, Fig.13に示すような 3 個の 連続体要素が 2 個のジョイント要素で連結され, 鉛直方 向の荷重下で変形するモデルを考える. 要素, 荷重とも 中心線に関して対象とすると，鉛直方向の変形に関して 左右半分は同図下のような簡略化したモデルに置き換え られる. $k_{1}$ と $k_{2}$ は連続体要素の鉛直方向ばね定数で, $k_{3}$ はジョイント要素のばね定数の鉛直成分， $\tau_{y}$ は，鉛 直方向の降伏荷重であり，Fig. 10（b) のような構成関 係を想定するものとする． $F_{1}, F_{2}$ はジョイント上端接 点に加わる鉛直荷重とし， $x_{1}, x_{2}$ は連続体要素の鉛直変 位とする. Fig. 13 のモデルで $F_{1}$ と $F_{2}$ が与えられると
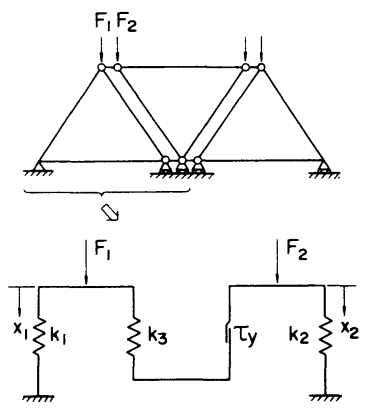

Fig. 13 Idealization of Combined Finite-Joint Elements.
解は次式で解析的に求まる.

$$
\begin{aligned}
& \left\{\begin{array}{l}
\left|x_{1}-x_{2}\right|<\tau_{y} / k_{3} \\
x_{1}=\frac{\left(k_{2}+k_{3}\right) F_{1}+k_{3} F_{2}}{k_{1} k_{2}+k_{2} k_{3}+k_{3} k_{1}}, \quad x_{2}=\frac{k_{3} F_{1}+\left(k_{1}+k_{3}\right) F_{2}}{k_{1} k_{2}+k_{2} k_{3}+k_{3} k_{1}}
\end{array}\right. \\
& \left\{\begin{array}{l}
\left|x_{1}-x_{2}\right| \geqq \tau_{y} / k_{3} \\
x_{1}=\frac{F_{1}-s_{g n}\left(x_{1}-x_{2}\right) \cdot \tau_{y}}{k_{1}}, \quad x_{2}=\frac{F_{2}+s_{g n}\left(x_{1}-x_{2}\right) \cdot \tau_{y}}{k_{2}}
\end{array}\right.
\end{aligned}
$$

以上を荷重伝達法で解く場合の手順は,

(1) $j-1$ ステップの等価線形荷重 $P_{1, j-1}, P_{2, j-1}$ に対 して,

$$
\left.\begin{array}{l}
x_{1, j-1}=\frac{\left(k_{2}+k_{3}\right) P_{1, j-1}+k_{3} P_{2, j-1}}{k_{1} k_{2}+k_{2} k_{3}+k_{3} k_{1}} \\
x_{2, j-1}=\frac{k_{3} P_{1, j-1}+\left(k_{1}+k_{3}\right) P_{2, j-1}}{k_{1} k_{2}+k_{2} k_{3}+k_{3} k_{1}}
\end{array}\right\}
$$

を求める.

(2) $x_{1, j-1}, x_{2, j-1}$ に対して, 各部材反力を求める.

$$
\left\{\begin{array}{l}
\varphi_{1, j-1}=k_{1} x_{1, j-1}+s_{g n}\left(x_{1, j-1}-x_{2, j-1}\right) \cdot \tau_{y} \\
\varphi_{2, j-1}=k_{2} x_{2, j-1}-s_{g n}\left(x_{1, j-1}-x_{2, j-1}\right) \cdot \tau_{y}
\end{array}\right.
$$

(3) 真の荷重に対する調整外力を求める.

$f_{1, j-1}=F_{1}-\varphi_{1, j-1}, f_{2, j-1}=F_{2}-\varphi_{2, j-1}$

(4) $P_{1, j-1}, P_{2, j-1}$ に調整外力を加え, $j$ ステップの等 価線形外力 $P_{1, j}, P_{2, j}$ を求める.

(5) (1)〜 (4)を繰り返して, $\left|x_{1, n}-x_{1, n-1}\right|, \mid x_{2, n}-$ $x_{2, n-1} \mid$ が十分小さくなるまで続ける.

ここで，(4)の過程で調整外力を大きくしたらどうなる かを考えてみる.すなわち，

(4) ${ }^{*} \quad P_{1, j}=P_{1, j-1}+\omega f_{1, j-1}, \quad P_{2, j}=P_{2, j-1}+\omega f_{2, j-1}$

としてみるのである。 $\omega$ は $f_{1, j-1}, f_{2, j-1}$ を大きく評価す るための係数であるから 1 以上でなければならない.

$\omega \geqq 1$

$\omega=1$ のときは本来の荷重伝達法である.

式（8) 〜式（11）を書き直して次の行列表示の漸化 式を導ける.

$$
\boldsymbol{X}_{\boldsymbol{j}}=\omega \boldsymbol{F}+[\boldsymbol{M}] \boldsymbol{X}_{j-1}
$$

$$
\text { ここに, }
$$

$$
\begin{aligned}
& X_{j}=\left[\begin{array}{ll}
x_{1, j} & x_{2, j}
\end{array}\right]^{r} \\
& \boldsymbol{F}=\frac{1}{k_{1} k_{2}+k_{2} k_{3}+k_{3} k_{1}} \\
& \cdot\left[\begin{array}{c}
\left(k_{2}+k_{3}\right)\left(F_{1}-\bar{s}_{g n} \cdot \tau_{y}\right)+k_{3}\left(F_{2}+\bar{s}_{g n} \cdot \tau_{y}\right) \\
k_{3}\left(F_{1}-\bar{s}_{g n} \cdot \tau_{y}\right)+\left(k_{1}+k_{3}\right)\left(F_{2}+\bar{s}_{g n} \cdot \tau_{y}\right)
\end{array}\right]
\end{aligned}
$$

$$
\begin{aligned}
& {[M]=\frac{1}{k_{1} k_{2}+k_{2} k_{3}+k_{3} k_{1}}} \\
& \cdot\left[\begin{array}{cc}
(1-\omega) k_{1}\left(k_{2}+k_{3}\right)+k_{2} k_{3} & -k_{2} k_{3} \omega \\
-k_{1} k_{3} \omega & (1-\omega) k_{2}\left(k_{3}+k_{1}\right)+k_{3} k_{1}
\end{array}\right]
\end{aligned}
$$


$\bar{s}_{g n}$ は $s_{g n}\left(x_{1, j}-x_{2, j}\right)$ の略であり $x_{1, j} \gtrless x_{2, j}$ に応じて士を とるが, 収束計算の過程では通常変化しない.

行列 $[M]$ の固有値の絶対値の最大値を $|\lambda|_{\text {max }}$ とし, 各 行列のノルムを $\left\|\boldsymbol{X}_{\boldsymbol{j}}\right\|$ 等と書くと, 式 (13) よりノルム の間に次の不等式が成立する.

$$
\left\|\boldsymbol{X}_{j}\right\| \leqq \omega\|\boldsymbol{F}\|+|\lambda|_{\max } \cdot\left\|\boldsymbol{X}_{j-1}\right\| \cdots
$$

したがって， $n$ ステップでは次式が成立する.

$$
\left\|\boldsymbol{X}_{n}\right\| \leqq \frac{\omega\|\boldsymbol{F}\|}{1-|\lambda|_{\max }}+|\lambda|_{\max }^{n} \cdot\left\{\left\|\boldsymbol{X}_{0}\right\|-\frac{\omega \boldsymbol{F}}{1-|\lambda|_{\max }}\right\}
$$

したがって,$n \rightarrow \infty て ゙ X_{n}$ が収束するためには,

$$
|\lambda|_{\max }<1
$$

の条件が必要である. 行列 $[M]$ の固有値は次式となる.

$$
\lambda_{1}=1-\omega, \quad \lambda_{2}=1-\omega k_{1} k_{2} /\left(k_{1} k_{2}+k_{2} k_{3}+k_{3} k_{1}\right)
$$

a) $\omega>\left(k_{1} k_{2}+k_{2} k_{3}+k_{3} k_{1}\right) /\left(k_{1} k_{2}\right)$ の場合

$$
|\lambda|_{\max }=\omega-1>\frac{k_{1} k_{2}+k_{2} k_{3}+k_{3} k_{1}}{k_{1} k_{2}}-1=\frac{k_{3}}{k_{1}}+\frac{k_{3}}{k_{2}}
$$

本論文で扱う問題におけるジョイント要素では, 前述し たように, $k_{3}>k_{1}, k_{2}$ とするのが普通であるから結局

$$
|\lambda|_{\max }>1
$$

となり，この場合は式（19）の条件を満足しない.

b) $\left(k_{1} k_{2}+k_{2} k_{3}+k_{3} k_{1}\right) /\left(k_{1} k_{2}\right)>\omega \geqq 2\left(k_{1} k_{2}+k_{2} k_{3}\right.$

$$
\left.+k_{3} k_{1}\right) /\left(2 k_{1} k_{2}+k_{2} k_{3}+k_{3} k_{1}\right) \text { の場合 }
$$

$|\lambda|_{\max }=\omega-1$

したがって, 式 (19) の条件とb) の条件とから

$2>\omega \geqq 2\left(k_{1} k_{2}+k_{2} k_{3}+k_{3} k_{1}\right) /\left(2 k_{1} k_{2}+k_{2} k_{3}+k_{3} k_{1}\right)$ を得る.

c) $2\left(k_{1} k_{2}+k_{2} k_{3}+k_{3} k_{1}\right) /\left(2 k_{1} k_{2}+k_{2} k_{3}+k_{3} k_{1}\right)>\omega \geqq 1$ の場合

$$
|\lambda|_{\max }=1-\omega k_{1} k_{2} /\left(k_{1} k_{2}+k_{2} k_{3}+k_{3} k_{1}\right)
$$

となるが，明らかに 1- $|\lambda|_{\max }>0$ であり式（19）の条 件を満足している. 結局, $X_{n}$ の収束のための必要条件 式 (19) は $\omega$ に関する次の不等式と等価である.

$$
2>\omega \geqq 1
$$

逆に, 式 $(19)^{*}$ が成立する場合, $[M]$ の固有ベクトル から成る変換行列 $[R]$ を用いて $\boldsymbol{X}_{j}$ を以下のように変換 する.

$$
[R]=\frac{1}{k_{1}}\left[\begin{array}{cc}
k_{1} & -k_{2} \\
k_{1} & k_{1}
\end{array}\right],[R]^{-1}=\frac{1}{k_{1}+k_{2}}\left[\begin{array}{cc}
k_{1} & k_{2} \\
-k_{1} & k_{1}
\end{array}\right]
$$

$\boldsymbol{Y}_{j}=\left[\begin{array}{ll}Y_{1, j} & Y_{2, j}\end{array}\right]^{T}$

$\boldsymbol{X}_{\boldsymbol{j}}=[R] \boldsymbol{Y}_{j}$

式（13）は次のようになる.

$\boldsymbol{Y}_{j}=\omega[R]^{-1} \boldsymbol{F}+[R]^{-1}[M][R] \boldsymbol{Y}_{j-1}$

$\xi=\left[\begin{array}{ll}\xi_{1} & \xi_{2}\end{array}\right]^{T}=[R]^{-1} \boldsymbol{F}$

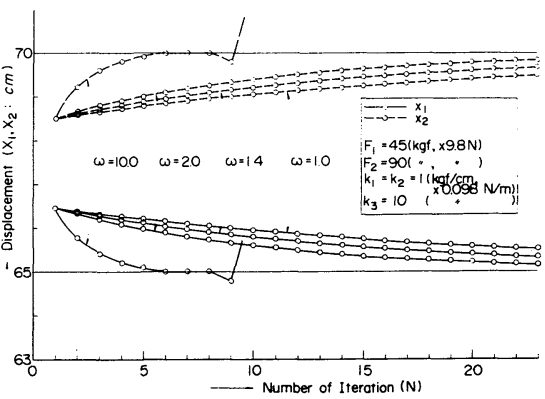

Fig. 14 State of Convergence of Iterative Nonlinear Calculations.

$$
\xi_{1}=\frac{F_{1}+F_{2}}{k_{1}+k_{2}}, \quad \xi_{2}=\frac{\left.k_{1} \mid k_{1}\left(F_{2}+\bar{s}_{g n} \cdot \tau_{y}\right)-k_{2}\left(F_{1}-\bar{s}_{g n} \cdot \tau_{y}\right)\right\}}{\left(k_{1}+k_{2}\right)\left(k_{1} k_{2}+k_{2} k_{3}+k_{3} k_{1}\right)}
$$

とおくと, 式 (24) は次のように書ける.

$$
\boldsymbol{Y}_{j}=\omega \xi+\left[\begin{array}{cc}
1-\omega & 0 \\
0 & 1-\omega k_{1} k_{2}\left(k_{1} k_{2}+k_{2} k_{3}+k_{3} k_{1}\right)
\end{array}\right] \boldsymbol{Y}_{j-1}
$$

上式を初期値を用いた第 $n$ ステップの成分で書き， $n$ $\rightarrow \infty$ とすると式 (19)*が成立しているから，

$$
Y_{1, \infty}=\xi_{1}, \quad Y_{2, \infty}=\xi_{2}\left(k_{1} k_{2}+k_{2} k_{3}+k_{3} k_{1}\right) /\left(k_{1} k_{2}\right)
$$

を得る. 式 (27) と式 (25) とを式 (23) に代入すると

$$
x_{1, \infty}=\frac{F_{1}-\bar{s}_{g n} \cdot \tau_{y}}{k_{1}}, x_{2, \infty}=\frac{F_{2}+\bar{s}_{g n} \cdot \tau_{y}}{k_{2}} .
$$

を得る. 式 (28) は式 ( 7 ) そのものであり, 式 (19)*が 成立すれば, 荷重伝達法の繰り返し計算が正解に収束す ることが示された．すなわち，調整外力に加速係数 $\omega$ をかけた荷重伝達法の繰り返し収束計算が収束するため の必要十分条件が式 (19)*であることが証明された.

以上を具体的な計算例で示したものが Fig. 14 である. $\omega=1,1.4,2.0$ の順に収束が早くなっているのがわかる. 式 (19)*の条件を越えて $\omega=10$ とすると収束が著しく 加速されるが, 収束精度を大幅に上げようと, 繰り返し 計算をさらに進めると, 突然発散する.これは, 式 (26) より明らかなように，正規化された変位の一方の収束条 件が満足されないことによる.

\section{8. 結 論}

上記所論を要約すると以下のようにいえる.

（1）土質材料を用いた模型実験におけるような低拘 束圧下の強さ定数を三軸圧縮試験により求めると, ゴム スリーブの拘束による影響か強く現われ, 特に, 粘着力 に大きな誤差を伴うことを示した. ついで，ゴムスリー ブの影響を除く方法を提案し, 求められた強さ定数を用 いた計算結果が実験結果をよく近似することからその妥 当性を示した。 
（2）2種類の砂を用いた模型斜面の傾斜による静的 破壊実験により, 破壊過程を明らかにすると同時に, 静 的破壊には天端幅の影響はなく, 斜面勾配の影響が支配 的であることを示した．また，破壊加速度に及ぼす斜面 勾配の影響は, 静的破壊と動的破壊とで類似した様相を 示すことを明らかにした。

（3）模型斜面を有限要素分割し，隣接要素間すべて にジョイント要素を配置した数学モデルで非線形解析に より静的破壊実験をシミュレートした結果, 実験結果を 非常に良好に再現できることを示した.

（4） シミュレーションにおいては, 引張りクラック やすべりの発達過程を詳細に追跡できるうえに実験にお ける破壊過程を良好に説明できるので，実験と解析を総 合して斜面の静的破壊機構を説明できた.

（5）荷重伝達法の繰り返し収束計算において, 調整 外力に加速係数をかけることにより収束が早くなること を示し, 収束するための必要十分条件から, 加速係数が 1 以上 2 末満であることを示した. 1 の場合が通常の荷 重伝達法であるので, この方法が必ず収束解をもつこと を証明したことにもなる.

謝 辞：本実験を行うにあたり, 東京電力株式会社 と電力中央研究所には種々のご便宜を図って頂いた。 ま た, 実験の遂行にあたっては, 前田設計株式会社の近藤 和男氏と埼玉大学卒業生の井野正男君には, 全面的にご 協力を頂いた.ここに記し, 併せ深甚の謝意を表したい.

1) Japanese National Committee on Large Dams, Earthquake Resistant Design Features of Dams in Japan, Earthquake Resistant Design for Civil Engineering Structures in Japan, Compiled by JSCE, pp. 2 29, 1984.

2) Watanabe, H. : Numerical Methods of Seismic Analyses for Rock and Earthfill Dams and Verification of its Reliability through Both Model Tests and Observations on an Actual Dam, Proc. Intern. Symp. on Criteria and
Assumptions for Numerical Analysis of Dams, Swansea, U.K., 8-11, pp. 745 765, Sept. 1975.

3) Kokusho, T. and Iwatate, T. : Scaled Model Tests and Numerical Analyisis on Nonlinear Dynamic Response of Soft Grounds, Proc. JSCE, No.285, pp. 57 67, May 1979 (in Japanese).

4) Watanabe, H. : The Effect of Damping Constant on the Accuracy of Seismic Design Calculations for Soils and Foundations, Proc. 8th WCEE, San Francisco, Vol. III, pp. 1001 1008, 1984.

5) Watanabe, H. and Tochigi, H. : A Consideration on the Equivalent Linearization of Restoring Force Characteristics of Structures, Proc. JSCE, No. 356/ I -3, pp. 195 $\sim 205,1985.4$.

6) Seed, H. B., Lee, K. L., Idriss, I. M. and Makdsi, F. : Analysis of the Slides in the San Fernando Dams during the Earthquake of February 9, 1971, Report No. EERC 73-2, Univ. Calif., Berkeley, 1973.

7) Nakamura, K. et al. : Dynamic Deformation Analysis of an Embankment, Proc. 17th Japan National Conference on Soil Mechanics and Foundation Engineering, pp. 1889 1892, 1982 (in Japanese).

8) Seed, H. B. : Consideration in the Earthquake-Resistant Design of Earth and Rockfill Dams, the Rankine Lecture 1979, Geotechnique, 29, No.3, pp. 215 263, 1979.

9) Watanabe, H., et al. : Evaluation of EarthquakeInduced Sliding in Rockfill Dams, Soils and Foundations, Vol. 24, No.3, pp.1 14, Sept. 1984.

10) Mikuni, E., et al. : Dynamic Structural Model Tests on Nagano Dam, Civil Engineering Laboratory Report, Electric Power Development Company, 1967 (in Japanese).

11) Toki, K., et al. : Seperation and Sliding between Soil and Structure during Strong Ground Motion, Proc. JSCE, No. 302, pp. 31 41, Oct., 1980.

12) Goodman, R. E. : Methods of Geological Engineering in Discontinuous Rocks, West Publishing Co., 1976.

13) Toki, K. and Miura, F. : Non-linear Seismic Response of Soil-structure Interaction System, Proc. JSCE, No. 317, pp. $61 \sim 68,1982$.

(1985.12.16 - 受付) 